\title{
Polish Exports in the EU Market and Its Competitiveness in the Face of the Crisis
}

\author{
Ewa Szymanik \\ Cracow University of Economics, Kraków, Poland
}

\begin{abstract}
This article presents the problem of the competitiveness of the economy in relation to foreign trade, with particular emphasis on the current crisis. The research results are presented here, relate to the exchange between Poland and the EU countries in the field of industrial goods during the time of the association and membership in this group. They show that Polish competitiveness is improving slowly, but the structure of our exports is still unfavorable, since it is dominated by products with a low degree of processing. However, recent years have seen some improvements as evidenced by the results from the period of recession. Researches were done by using the most popular indicates like revealed comparative advantage (RCA) and intra-industry trade (IIT). Also the influence of some other factors, apart from the association, on the competitiveness of exports was discussed and the conclusions from the research were presented.
\end{abstract}

Keywords: export, competitiveness, European Union, industrial goods, crisis

\section{Introduction}

Since the end of the 1980s, the economic and political interests of Poland have turned more and more towards West European countries, among which the member states of the contemporary European Communities occupied a special place. Our country was interested in a faster pace of transformation and an approximation to the structures of these states, hence in 1988 the diplomatic relations between Poland and the European Communities were established, which meant a regulation of mutual relations that led to cooperation. A significant change from the point of view of the economic development was the signing by Poland of the so-called Europe Agreement in 1991, establishing an association between Poland and the European Communities and their member states. This Agreement was supposed to be the first step towards our entry into this group.

The year 2004 brought a long-awaited accession to the EU structures and quite far-reaching changes. Most of all, it meant a complete opening of absorptive markets of our most important partners and the ability to expand trade with countries so far less significant in our trade on preferential terms without the possibility of discrimination. Not without significance was the fact that the EU economy was developing dynamically and was quite receptive.

Ewa Szymanik, Ph.D., Department of Microeconomics, Cracow University of Economics.

Correspondence concerning this article should be addressed to Ewa Szymanik, Rakowicka 27, 31-510 Kraków, Poland. E-mail: szymanie@uek.krakow.pl. 
The change came in 2007, when the world was engulfed by the economic crisis rooted in the United States. It strongly influenced the majority of the EU countries, Poland, however, remained on the sidelines. Therefore, it is worth asking a question whether and to what extent the economic downturn affected Polish international trade and related issues.

Economic and political changes connected with the need to adapt to the rules of the world trade brought to our country an entirely new task-the necessity to improve the international competitiveness of the economy. This competitiveness is defined in the literature in various ways since there is no universal definition. The difficulty arises from the fact that this term refers both to the ability to participate in a contest, as well as an ex-post evaluation of its results, therefore it consists of both the dynamic element related to the analysis of the factors influencing the long-term ability to compete, as well as a static element expressed in the assessment of that ability at a time. Another problem is a very broad conceptual aspect leading to a situation that definitions proposed in the literature are either general with low research usability, or detailed, yet referring only to a small sector of the economic life of a country. Moreover, some economists define competitiveness according to the scope of the research. Wierzbołowski (1995) who differentiates competitiveness in the strict sense, which can also be called micro-competitiveness, and in the broad sense-macro-competitiveness, or Flejterski (1984) who in addition distinguishes meso-competitiveness that is exports of good of a particular industry or branch. One can also examine economy in a wider aspect, taking into consideration many factors, for instance, by means of Zintegrowany Model Konkurencyjności Gospodarki (the integrated model of competitiveness) (Jagiełło, 2008).

In this article, a detailed definition will be used focusing primarily on foreign trade. According to it the international competitiveness of economy is its price competitiveness and non-price understood as an attractiveness of commodities by a particular country and services, as well as products that are substitutes for imported goods (Hübner, 1994). A necessity of improving economic situation was also a consequence of integration efforts-raising economic level fosters development of exchange, also with the EU countries, and further economic growth.

The level of competitiveness achieved so far by the Polish economy is a result of long-and medium-term processes, to a large extent determined by the conditions inherited from the centrally planned economy period, and then modified by changes made in the process of transformation, as well as during the time of being a candidate and functioning of our country in terms of membership in the EU structures, while the latter being less important for trade, since the process of liberalization of exchange for most commodities ended much earlier. The level of competitiveness is subject to constant slow changes being a result of those processes and an influence of constantly new impulses coming from the global economy such as the current crisis. Certainly, the opening of the economy contributed to the inflow of foreign direct investment being a factor contributing to the modernization of the industry structure, and consequently, also trade patterns. However, there is no doubt that both current and future competitiveness of Poland depends primarily on changes in the marketization of the economy, as well as enhanced actions of government in the field of legislation facilitating the more effective economic development of the country and global development trends, such as general economic crises.

The attempt taken in the present article to evaluate the changes of the competitiveness of the Polish exports of industrial goods presents the situation from the moment of the accession to the European Union up to the year 2010. Due to the lack of recent public data published by the Central Statistical Office, the evaluation of the 
situation in the crisis is not complete, and it includes only the years from 2008 to 2010. This research is a continuation of the work carried out by numerous authors in earlier years, hence, the reference in the analysis to the results obtained by other researchers mainly Misala and Pluciński (2000), as well as previous works of the author of this article.

\section{Polish Exports of Industrial Goods From the Moment of the Association With the EU-Ratio Analysis}

From 1 March 1992 the Interim Agreement being part of the Association Agreement was in force in relations between Poland and the countries of European Communities. It introduced regulations of the trade exchange of industrial goods and contained a detailed schedule of the liberalization of the access to our market for individual groups of goods. The schedule did not include a large competitive advantage of the community producers, and therefore Polish producers had to perform a number of changes both in the mode of production, as well as in acquiring and consolidating their positions in the western markets, which also required our country make appropriate amendments in legislation and trade regulations.

Determining the changes of the competitiveness of the economy, defined as the attractiveness of a country exports of commodities, services, and products that are substitutes for imported goods, is possible through the index analysis of revealed comparative advantage (RCA), intra-industry trade (IIT) and shares of individual commodity groups in exports and imports of Poland and the EU. The use of these methods of measuring competitiveness allows tracing its changes in the analyzed period. A fuller picture can be obtained by completing this analysis with the impact of factors that are difficult to measure, such as state policy. It should be noted that some authors do not share this view calling for a broader approach to the issue from the microeconomic side (Lipowski \& Wziątek-Kubiak, 2000).

The analysis used the RCA indices calculated by logarithmic method and IIT expressed as a percentage. The choice of the method of counting was dictated by the intention to allow comparisons with the results of research conducted by the authors mentioned in the introduction.

RCA indices:

$$
R C A_{i}=\ln \left[X_{i} / M_{i}: \Sigma X_{i} / \Sigma M_{i}\right]=\ln X_{i}-\ln M_{i}
$$

where $X_{i}$ : a value of exports of commodity group $i$;

$M_{i}$ : a value of exports of commodity group $i$;

$R C A_{i}$ value less than zero indicates a lack of, while $R C A_{i}$ greater than zero-the occurrence of revealed comparative advantage and intensity of inter-branch trade and international division of labor.

IIT indicator:

$$
I I T=\left[\frac{\left(X_{i}+M_{i}\right)-\left|X_{i}-M_{i}\right|}{X_{i}+M_{i}}\right] \cdot 100
$$

Values close to $100 \%$ indicate high intensity of the exchange.

The study of competitiveness for the years 1992-1998 was carried out by Misala and Pluciński (Misala \& Pluciński, 2000; Pluciński, 1997).

The authors showed in their works that the inter-branch trade prevailed in the Polish exchange with the EU at that time. This phenomenon attests to the considerable maladjustment of the structure of the Polish exports to 
the EU level, since the intra-branch exchange dominates among the partners of a similar level of development. One of the reasons for this state was and still is the existing technological gap, especially in the field of high-tech goods (group 7 according to SITC classification).

The situation in the next period is similar (see Table 1).

Table 1

Average Values of Indices IIT (in Percent) and RCA in the Exchange Between Poland and the European Union for SITC Groups 3, 5-9 and for Group 7

\begin{tabular}{lllllllllllll}
\hline Rok & 1999 & 2000 & 2001 & 2002 & 2003 & 2004 & 2005 & 2006 & 2007 & 2008 & 2009 & 2010 \\
\hline IIT for every group & 50.39 & 52.87 & 53.93 & 90.71 & 92.84 & 94.69 & 99.59 & 98.48 & 99.88 & 99.99 & 93.89 & 92.01 \\
IIT for the group 7 & 67.28 & 79.84 & 88.26 & 91.48 & 95.47 & 98.9 & 95.86 & 92.28 & 93.85 & 94.16 & 80.99 & 80.78 \\
RCA for every group & -0.47 & -0.36 & -0.22 & -0.19 & -0.14 & -0.11 & -0.01 & 0.03 & -0.01 & -0.0001 & 0.12 & 0.16 \\
RCA for the group 7 & -0.68 & -0.41 & -0.24 & -0.17 & -0.091 & -0.02 & 0.08 & 0.16 & 0.12 & 0.18 & 0.39 & 0.39 \\
\hline
\end{tabular}

Note. Source: Own calculations based on the data from Yearbook of Foreign Trade Statistics (various years). Since 2007 data cover the EU-27.

The results presented in Table 1 indicate the dominance of the inter-branch exchange in Polish trade with the EU as it was in the previous years (as demonstrated by the authors of the study mentioned earlier), although this trend is clearly slowed. An increase in IIT indicator means a positive development trend, especially in the group of high-tech goods (machinery and transport equipment). Advantageous results for past years, indicating an improvement of the commercial structure should not, however, are taken as the evidence that there was a radical change at that time. It was a result of the economic recovery in the EU countries continuing for several years, and the inflow of foreign direct investment, which was associated with a facilitated access to the EU market through distribution channels at the disposal of enterprises investing in Poland. Deteriorating results for years 2009-2010 indicate the fact that there were signs of the crisis in the Polish economy being largely a conveyance of the problems experienced by the EU countries. One should remember that the course of the world business cycle is not identical in all economies but there are time delays concerning also Poland. It should also be noted that in years 2004-2008 Polish exports to the countries of the "old" EU grew at an average annual rate of $16.5 \%$ while in five years preceding the accession to the EU the overall rate was $13.6 \%$. After the extension of the group sales to new member states grew significantly faster (by $24.3 \%$ per year). The slower rate of growth of exports into countries of the EU-15 also meant a decrease in its share of the Polish sales abroad and it was quite significant (from 68.8\% in 2003 to 61.4\% in 2008) (Mroczek, 2009; Statisitcal Yearbook of Poland, various years). It is still a significant share but if one takes into account the fact that a share of these countries in an exchange is regarded as an important indicator of the degree of integration, there may be a paradoxical situation. However, it certainly means that Poland is becoming a more and more important player on the international stage, less dependent on its closest (geographically and politically) neighbours, as well as it is a country increasingly important in the intra-EU exchange (its share in imports within the group increased from 2.1\% in 2000 to 3.7\% in 2009 and 3.9\% in 2010, while exports from $1.5 \%$ to $3.5 \%$ and $3.8 \%$ respectively) (Retrieved from http://epp.eurostat.ec.europa.eu/). Also the diversification of the exchange is advantageous especially in the conditions of the crisis. One should pay attention to the fact that the value of IIT index indicating resemblance of exchange structures also increased in the first year of the crisis but decreased in the subsequent ones. On the one 
hand, it should be remembered that this state reflects the lowering of the average level of the economy in the whole Union, which in 2007 was joined by two quite poor countries-Bulgaria and Romania. On the other hand, however, one should not give any exaggerated significance to this situation, since it is necessary to remember that entering the EU structure was preceded by the long-lasting process of adjustment connected with the economic development of these states. As it appears in Table 1 with reference to the IIT indicator, the crisis did not affect negatively the resemblance of exchange structures, quite the opposite-an improvement took place, and the results of the last two years indicate the impact of the crisis on the Polish economy and seeking savings by partners, which is reflected by a decrease in purchases in the EU countries and the search for cheaper suppliers, primarily in Asia. The approximation of the structures, especially in group 7, is probably not only the result of a fairly good condition of the Polish economy at the beginning of the collapse, but also of the deterioration of the situation in other member states of the group, thus clear shortening of the distance, which yet deepened considerably in the consecutive years as a consequence of the above-mentioned circumstances. However, one can cautiously assume the permanence of the transformation in the structure of the Polish trade and the slow improvement of the competitiveness, especially that after the accession to the EU there have been changes in the exchange structure in group 7 (machinery and transport equipment), that is the importance of parts and components has decreased while the importance of finished goods has increased which contributes to the increase in the added value in transport (Mroczek, 2009).

RCA ratio analysis shows that in the trade with the EU, Poland is still a much weaker partner, although in recent years there has been a slight advantage. This means that the approximation of the structures is increasing, which may be a result of both the improvement of the situation in the Polish economy despite the crisis, as well as the above-mentioned decrease in the average level of the EU-27 economy as a result of the expansion. A technological gap during the period of association still existed for group 7 which meant a growing development distance between Poland and our EU partners. The change took place only after the accession to the EU. This could be due not so much to the improvement of the competitiveness, but rather to the fact that most of the new members of the group are not leading manufacturers of technologically advanced goods. Comparative advantages appeared in the areas of highly processed products, however, this is the result not so much of a radical improvement in the industry but rather of the extension of the group by the above-mentioned countries. An increase in the advantage for this group has been significant since 2008. It is confirmed by the growth of importance of Poland discussed earlier in the field of trade in more technologically advanced products from this branch. It follows that the structure of the Polish economy has not changed much during the pre-accession economic changes and after accession to the EU, although in recent years clearly positive transformations which have not been disturbed by the crisis are noticed. One can even get the impression that the latter factor has played a positive role in transformations of the structure of Polish foreign trade within the Union. It also seems that, despite the negative trends in the global economy, positive changes in trade in industrial goods are clearly visible, but mainly in comparison with newly admitted countries. Positive changes associated with this, both in exports (growing share of high-tech goods), as well as in the whole economy are taking place very slowly.

This situation is shown in detail in Table 2. 
Table 2

Formation of Indicators of Intra- and Inter-Branch Trade Between Poland and the European Union in the Discussed Groups of Commodities (IIT Values-A Percentage)

\begin{tabular}{|c|c|c|c|c|c|c|c|c|c|c|c|c|c|c|c|c|c|c|c|}
\hline \multirow[t]{2}{*}{ Country } & \multirow{2}{*}{$\begin{array}{l}\text { SITC } \\
\text { group }\end{array}$} & \multicolumn{2}{|c|}{1999} & \multicolumn{2}{|c|}{2003} & \multicolumn{2}{|c|}{2004} & \multicolumn{2}{|c|}{2005} & \multicolumn{2}{|c|}{2006} & \multicolumn{2}{|c|}{2007} & \multicolumn{2}{|c|}{2008} & \multicolumn{2}{|c|}{2009} & \multicolumn{2}{|c|}{2010} \\
\hline & & RCA & IIT & RCA & IIT & RCA & IIT & RCA & IIT & RCA & IIT & RCA & IIT & RCA & IIT & RCA & IIT & RCA & IIT \\
\hline & 3 & 0.41 & 79.78 & 1.05 & 51.77 & 0.76 & 63.94 & 0.62 & 70.09 & 0.42 & 79.25 & 0.08 & 96.16 & 0.04 & 98.21 & 0.004 & 99.8 & 0.14 & 92.89 \\
\hline & 5 & -1.82 & 28 & -1.56 & 34.77 & -1.54 & 35.19 & -1.14 & 48.47 & -1 & 53.98 & -0.93 & 56.49 & -0.88 & 58.79 & -0.87 & 58.88 & -0.07 & 96.36 \\
\hline \multirow[t]{4}{*}{ EU } & 6 & -0.38 & 81.08 & -0.22 & 89.06 & -0.17 & 91.65 & -0.11 & 94.52 & -0.15 & 92.53 & -0.07 & 96.34 & 0.005 & 99.78 & -0.08 & 95.96 & 0.35 & 82.63 \\
\hline & 7 & -0.68 & 67.28 & -0.091 & 95.47 & -0.02 & 98.9 & 0.08 & 95.86 & 0.16 & 92.28 & 0.12 & 93.85 & 0.18 & 94.16 & 0.39 & 80.99 & 0.27 & 86.51 \\
\hline & 8 & 0.51 & 75.25 & 0.66 & 68.24 & 0.66 & 68.19 & 0.68 & 67.11 & 0.7 & 66.55 & 0.67 & 67.83 & 0.56 & 72.86 & 0.71 & 65.82 & 1.11 & 49.6 \\
\hline & 9 & -1.87 & 26.62 & -1.001 & 53.73 & -0.55 & 73.22 & 0.98 & 54.42 & -2.08 & 22.14 & -2.58 & 14.12 & -2.51 & 15.01 & -3.07 & 8.86 & 0.36 & 82.04 \\
\hline
\end{tabular}

Notes. Source: Own calculations based on the data from Yearbook of Foreign Trade Statistics (various years). Due to the lack of public data for Cyprus and Malta for 2004, the results for the EU-25 are from 2005. Data from 2007 include Bulgaria and Romania.

The data presented in Table 2 confirm the above-written findings. It should be noted that a quite high specialization in the exchange of products of group 3 (mineral fuels and lubricants) is alarming, although during the crisis a significant decrease was noticeable. Here a sale of coal prevails, especially of black one, which is very susceptible to economic fluctuations, as well as it has a great competition. It appears from the above dissertations that our country should gradually give its exports up, trying to replace this product with another, especially from groups with a higher share of technology. Another argument is the necessity of gradual replacement of fuels that emit environmentally harmful carbon dioxide (in the process of processing), which will result in a further decline in its exports. In recent years, however, one could notice a decrease in this advantage and significant approximation of exchange structures, which indicates positive changes in the Polish economy. Nevertheless, all the time a significant (albeit gradually declining) gap in trade in chemical goods (group 5) remains-no comparative advantage here at all (negative values), and low (compared with the other groups) IIT indicators confirm little involvement of Poland in the development of those sectors of the economy during the analyzed period, though again, one can see a gradual improvement, especially a clear acceleration in last two studied periods. The situation is much better in group 6 (manufactured goods classified chiefly by material)—in the last year even a slight comparative advantage was noted. The exchange structure of Poland with the EU countries is gradually improving. This is due to a large variety of goods belonging to this group and gaining new markets for successive products by Polish companies, copes better and better on the EU markets, especially in new countries. However, a significant improvement of indicators for group 7 (machinery) indicates beneficial transformations in the economy of our country that is modernization of the production structure which was described earlier (even though this group, due to the large production of durable and quite expensive products, has experienced some clear fluctuations in the field of structure resemblance in recent years which was a result of shifting of trade directions).

In the case of various industrial products (group 8), the comparative advantage is maintained for the whole analyzed period on a similar, not very high level, though during the crisis a downward trend appeared. At the same time the intra-branch exchange index was constantly decreasing until the crisis, despite an increase in 2008. This means that Poland initially resigned from the approximation of the exchange structures of these products to increase specialization instead, but the time of the recession extorted on Polish companies was need to widen the 
assortment in order to stay at markets, which was apparently successful, although it was not a permanent change. This group includes very diverse goods, so it will probably continue to be subject to cyclical fluctuations associated with the transitional specialization in the area of exports of given products and replacing them after a while with other, more modern and more often sought by customers.

Goods from the last examined group 9 (not classified elsewhere) play a minor role in the Polish trade with the EU countries, so changes in this group have virtually no impact on the competitiveness of Polish exports (for majority of countries such exchange does not exist or its size is not statistically significant, this group reflects trade relations only with Germany, Italy, and Slovakia), though here you can see the widening of the gap between Poland and other countries.

Willingness declared for years to improve the competitive position of Poland on the European market requires some serious modernization of the trade pattern that is basing the exports on the development of modern branches of industry (especially high-tech), what in recent years is beginning to be visible. Estimates made by the European Commission show that the share of exports of these products in total Polish exports in 2004 amounted to only about $3 \%$. The global exports of these products accounted for a mere $0.15 \%$, with an average annual growth rate of $16.9 \%$ for this sector in our country (European Commision, 2008). This means that it is necessary to create conditions for such an economic growth that would be generated primarily by innovation, which would result in a significant increase in the competitiveness of Polish enterprises constituting the base for modernization and development of production (S. Lis \& W. M. Lis, 2004). Companies generating inflows of foreign direct investment might play the most important role in this process, because they have the greatest amount of capital and invest primarily in areas related to industrial engineering and transport. Investments flowing into Poland are high, which has been particularly evident in recent years. In 2006 it was 15,707 million Euros, in 2007—a record-breaking 17,222 million Euros. A consecutive year, which was already critical, was characterized by a very high drop-Poland attracted 10,118 million Euros, which is indeed almost half less, but still quite a high amount. The year 2009, the time of a deep slump, was associated with a further decline-Poland attracted 9,863 million Euros (Retrieved December 6, 2010, from http://www.paiz.gov.pl/polska_w_liczbach). Estimates that in 2010 this amount would be even less proved to be correct—-the inflow amounted to only 6,686 million Euros in 2011, although the situation clearly improved (data from the first three quarters indicate about 9,000 million Euros). However, it should be noted that despite the decline in the inflow of foreign direct investment, the state of the foreign trade and its competitiveness have not deteriorated seriously. It is the result of systematic changes made in the structure of the economy and increasingly general abilities of fast adaptation to a changeable market situation.

\section{Some Factors Influencing the Competitiveness of Polish Exports}

An important factor influencing the competitiveness of exports is a policy of a government, especially pro-exports activities. In Poland, there is no decisive action supporting exports, although appropriate programs have been enacted several times. Surveys conducted for many years among exporters by the Foreign Trade Research Institute (later Institute for Market, Consumption, and Business Cycles Research) showed that government programs have small reach and do not bring clear results. This is due to the fact that such program is the resultant of as many as three criteria: economic, social, and related to environmental protection (Czerwińska, 
2010). It is also usually subject to many changes under the pressure of powerful lobbies, such as mining, which want to ensure the biggest subsidies for their sectors or mitigating restructuring, often at the expense of other sectors of the economy. At the same time, however, there was an improvement in export performance in terms of value (for example, in years 2004-2008 the value of Polish exports and imports nearly doubled (Mroczek, 2009)), which may indicate the improvement of the competitiveness of Polish enterprises in the EU market despite little support from the state. This improvement is probably the result of a better and widely understood education of entrepreneurs including gaining experience in operating in those markets. It allows a formation of a long-term cooperation with foreign business partners connected with growing mutual trust, as well as possibilities of improving a quality of products associated with an access to new technologies and offering competitive prices compared with producers from other countries. Many factors affect this last element including the need to invest in modern machines, what in the long term, however, influences the improvement of the profitability and the competitiveness of Polish exports. Yet the crisis has clearly influenced this field, which is reflected among other things in the decrease in the competitiveness of Polish exports of goods from group 7 discussed earlier.

Another factor, which is the exchange rate policy, seems to have no significant effect on the development of exports (Polska. Raport o stanie gospodarki, various years; Polański, 1999; Kleinszmidt-Jędraszek, 1998), the authors of many works attribute an important role to it. Trade results attest to it when in the early 1990s, after the initial devaluation, Polish Zloty underwent real appreciation, while a rise in the exports took place. A similar situation happened in years 2000-2001. It follows that it was not the rate that controlled the changes in trade during this period, as these changes occur with a delay, but manipulations of the exchange rate in order to increase the competitiveness of Polish exports as it was sometimes suggested by the entrepreneurs surveyed by The Foreign Trade Research Institute (who do not resign from already established cooperation, if the rate of Polish Zloty rises), which can bring only short-term results, and will not affect its permanent improvement. Here structural and quality changes are more important. One should not undermine the relation between the exchange rate and the trade balance, which is difficult to prove, though, how strong it is due to its shifts in time and an influence of other factors (Szymanik, 2004). A suggestion appearing more often that the currency exchange rate is not a factor affecting the competitiveness of foreign trade.

The aforementioned growing inflow of foreign capital in the form of direct investment had also an influence on adjusting of Polish products to the EU standards, as well as entering our market by foreign companies, which is one of the consequences of the growing stabilization of the economy. The introduction of new technologies and management methods yielded results in the form of improving the quality and increasing in the competitiveness of exports of industrial products, and extensive contacts of these companies allowed the growth of trade turnover.

Table 3 shows the results achieved by companies with foreign capital in exports, measured by the RCA index by the following pattern:

$$
R C A(P)=\frac{u_{i j}}{u P L_{j}}
$$

where $P$ : a group of companies with foreign capital;

$u$ : share in exports of a commodity group $i$ in year $j$;

$u P L$ : share in total Polish exports in year $j$.

An indicator is greater than unity indicates the presence of a revealed comparative advantage in a certain 
class of goods ${ }^{1}$.

Due to the fact that according to the Central Statistical Office there is no direct transition between Polish Combined Nomenclature of External Trade Commodity (PCN) and SITC classification, indices calculated in the below table refer to main groups in PCN classification. A change of classification results from the fact that the publicly available data on shares in trade of enterprises with foreign capital are presented according to PCN classification.

Table 3 shows products from groups including processed goods in which the share of enterprises with foreign capital in exports is the biggest one.

Table 3

Revealed Comparative Advantage in Exports of Enterprises With Foreign Capital in Years 1998-2008 (Selected PCN Commodity Groups, Processed Goods)

\begin{tabular}{lllllllllllll}
\hline Group & 1998 & 1999 & 2000 & 2001 & 2002 & 2003 & 2004 & 2005 & 2006 & 2008 & 2009 & 2010 \\
\hline VII & 1.14 & 1.2 & 1.14 & 1.24 & 1.17 & 1.14 & 1.11 & 0.8 & 1.07 & 1.1 & 1.09 & 1.04 \\
X & 1.53 & 1.51 & 1.4 & 1.53 & 1.49 & 1.43 & 1.44 & 1.4 & 1.4 & 1.18 & 1.34 & 1.48 \\
XVI & 1.35 & 1.35 & 1.32 & 1.41 & 1.35 & 1.38 & 1.35 & 1.14 & 1.26 & 1.23 & 1.19 & 1.24 \\
XVII & 1.45 & 1.42 & 1.25 & 1.06 & 1.18 & 1.13 & 1.25 & 1.99 & 1.28 & 1.36 & 1.29 & 2.06 \\
XVIII & 0.99 & 1.07 & 1.008 & 1.11 & 1.22 & 1.33 & 1.39 & 0.62 & 1.26 & 1.29 & 1.35 & 0.41 \\
XX & 0.9 & 0.94 & 0.87 & 1.11 & 1.09 & 1.06 & 1.03 & 4.05 & 1.09 & 1.03 & 1.07 & 1.3 \\
\hline
\end{tabular}

Note. Source: Own calculations based on data from Science Center of Foreign Trade, Foreign Investment in Poland, Annual Report (various years). No datum available for year 2007 due to the absence in the source.

The presence of a clear competitive advantage (RCA $>1$ ) indicates the existence of the impact of foreign direct investment on the volume of exports. This means that such a relation exists in the above groups of goods, and on the other hand it allows noticing the interest of the foreign capital in these industries which generate the greatest profit and at the same time have high ratings in exports. These include the following groups: machinery and devices (XVI), transport equipment (XVII), paper and paperboard products (X). Group X is of particular interest to foreign capital due to a rise in prices of products of this industry in the world and constantly growing demand for its products. Exports of machinery and devices develop slightly slower but it seems that this group can, in the next few years, become the fastest growing branch of the economy. It should be noted that despite the presence of the crisis, there are no clear signs of an economic collapse. This means that companies with foreign capital have not been affected much by the recession.

As mentioned in the description of Table 3 there is a lack of data in public sources to calculate this indicator for 2007, however, it does not seem that there were significant differences associated with it. One should remember that the crisis began in the second half of the year and did not initially spread rapidly throughout the industry, hence it can most likely be assumed that the results for this year did not differ significantly from others.

\section{Summary and Conclusions}

The theoretical and empirical analysis performed above allows drawing the following conclusions:

- The highest rates of growth of intra-branch exchange concern groups of labour-intensive and

\footnotetext{
${ }^{1}$ Similar research for previous years was conducted earlier (Umiński, 1999). This author applied SITC classification, hence the results published in this work constitute the continuation of his studies.
} 
technologically advanced goods, but their shares in the EU market are not high, although the situation is improving more and more. The exchange has less complementary character which means that despite the weakness of our trade in relation to the EU, positive changes are slowly taking place. The improvement of indicators after the accession to the EU may be partly associated with the extension of the group by the countries not as technically advanced as the majority of the "old” states, so the position of Poland among them is stronger.

- During the time of the association and membership in the EU, there have been no major change in the competitiveness of Polish exports of industrial goods to this group. The competitiveness is improving slowly, but systematically, as indicated by the growing share in the exchange of technically advanced goods. However, it is difficult to predict how the situation will look like in the consecutive years of the crisis.

- Undoubtedly, a positive effect of the association has been a modernization of the Polish economy, including a change of the structure of the industry (also thanks to the inflow of foreign direct investment), although it is not possible to determine explicitly to what extent it has been caused by the association and related adjustments to the structures of the EU, and to what extent it is an effect of the transformation.

- The increase in exports of technically advanced goods is a factor that can be a starting point for further changes in the structure of the exchange, but the automotive industry dominant in this group is currently considered as declining. However, computer hardware, parts of aircraft and spacecraft, as well as telecommunications products and scientific equipment are beginning to play a greater role. It follows that it is necessary to increase expenditure on raising innovation in the economy and development of science-intensive industries, which in the long run will improve the position and competitive ability of Poland.

- A significant improvement of all the indicators at the beginning of the crisis and relatively small deterioration in subsequent years may, on the one hand, confirm an argument that the Polish economy is less affected by negative developments in the global economy, which is a reason for stating that positive changes, despite their slow nature, are stable and effective. On the other hand, however, there is a question whether one of the reasons for such situation is not the fact that our country has not even started preparations for the adoption of the common currency, especially did not stiffen the rate of Polish Zloty against Euro. Problems that have beset the Eurozone and the Baltic countries seem to confirm this, but a broader discussion of this issue is beyond the scope of this article. From another point of view, one can also conclude that the improvement of the indicators is a reflection of a generally good situation in Poland, which is a result of the dynamic development in recent years, including the beginning of a global collapse.

The conducted analysis shows that Europe Agreement, despite a number of positive changes which it extorted on the Polish economy, was not the only and dominant factor in transformations taking place in Poland. Undoubtedly, the signing of the agreement and implementation of the provisions it contained contributed to a faster transition to the market economy, but a role it played in changes, as well as its impact on improving the competitiveness, were only secondary. After the accession to the EU one should remember that the adjustment process has not been completed yet and further actions are needed, also from the government side, particularly in the field of legislation, to continually improve our position in that market, especially that from 1 May 2004 and then from 1 January 2007 this market has been expanded by other countries, which, as the author has tried to emphasize, brings new opportunities, but also leaves Poland facing greater economic challenges. Without a doubt it is important that all the changes have a permanent character and are based on solid foundations which proved to 
be true in the situation of Poland during the crisis, when it has turned out that our competitiveness has not experienced greater damage.

\section{References}

Czerwińska, E. (2010). Polityka przemysłowa, Report No. 107. Retrieved from https://www.biurose.sejm.gov.pl/teksty/r-10

European Commision. (2008). Science, Technology and Innovation-Key figures 2007. Luxembourg.

Flejterski, S. (1984). Istota i mierzenie konkurencyjności międzynarodowej. Gospodarka Planowa, 9, 390-394.

Foreign Investment in Poland, Annual Report. (various years). In J. Chojna (ed.). Warsaw: CSO.

Hübner, D. (1994). Międzynarodowa konkurencyjność gospodarki a strategia rozwoju. Retrieved from http://www.paiz.gov.pl/polska_w_liczbach

Jagiełł, E. M. (2008). Strategiczne budowanie konkurencyjności gospodarki (pp. 65-68). Warsaw: Wydawnictwo Poltext.

Kleinszmidt-Jędraszek, J. (1998). Kurs walutowy jako instrument polityki proeksportowej i antyinflacyjnej. Zeszyty Naukowe Uniwersytetu Szczecińskiego, No.226, Szczecin.

Lipowski, A., \& Wziątek-Kubiak, A. (2000). Konkurencyjność produkcji przemysłowej w Polsce w okresie transformacji. In J. Bossak, \& W. Bieńkowski (Eds.), Konkurencyjność gospodarki Polski w dobie integracji z Uniq Europejskq i globalizacji, SGH, Warsaw 2000.

Lis, S., \& Lis, W. M. (2004). Międzynarodowa konkurencyjność polskiej gospodarki w okresie transformacji systemowej. In A. Noga (Ed.), Zmiany instytucjonalne w polskiej gospodarce rynkowej. Wydawnictwo PTE, Warsaw.

Misala, J., \& Pluciński, E. M. (2000). Handel wewnq̨trzgałęziowy między Polskq a Uniq Europejskq: Teoria i praktyka. Warsaw: SGH.

Mroczek, W. (2009). Handel zagraniczny Polski po przystąpieniu do Unii Europejskiej. Wspólnoty Europejskie, No. 2.

Pluciński, E. M. (1997). Der Außenhandel der visegrad-Staaten während des transformationsprozesses. Warsaw: SGH.

Polański, Z. (1999). Polityka kursu walutowego w Polsce w latach 90: Stabilizacja, konkurencyjność i przepływy kapitałowe. Ekonomista, No. 1-2.

Polska. Raport o stanie gospodarki. (various years). Warsaw: Ministerstwo Gospodarki.

Statisitcal Yearbook of Poland. (various years). Warsaw: Central Statistical Office.

Szymanik, E. (2004). Konkurencyjność eksportu na przykładzie wymiany Polski z krajami Unii Europejskiej (pp. 180-185). Krakowska Szkoła Wyższa im. A.F. Modrzewskiego, Cracow.

Umiński, S. (1999). Handel zagraniczny przedsiębiorstw z udziałem kapitału obcego. Gospodarka Narodowa, No. 10.

Wierzbołowski, J. (1995). Państwo jako aktywny uczestnik kształtowania międzynarodowej konkurencyjności. In M. Lubiński, \& T. Smuga (Eds.), Międzynarodowa konkurencyjność gospodarki Polski-Uwarunkowania i perspektywy (pp. 21-22). Raporty. Studia nad konkurencyjnością, IRiSS, Warsaw, No. 35.

Yearbook of Foreign Trade Statistics. (various years). Warsaw: Central Statistical Office. 